\title{
Membership Positions and Problems Faced by Housing Cooperative Societies
}

\section{OPEN ACCESS}

Volume: 7

Issue: 2

Month: October

Year: 2019

P-ISSN: 2321-4643

E-ISSN: 2581-9402

Received: 6.9.2019

Accepted: 28.9.2019

Published: 03.10.2019

Citation:

Jeeva Rekha, B.

"Membership Positions and

Problems Faced by Housing

Cooperative Societies."

Shanlax International Journal of Management, vol. 7, no. 2 , 2019, pp. 70-76.

DOI:

https://doi.org/10.34293/

management.v7i2.720

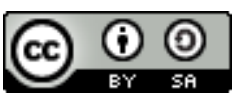

This work is licensed under a Creative Commons Attribution-ShareAlike 4.0 International License.

\author{
B.Jeeva Rekha \\ Assistant Professor in Commerce, Sri Vasavi College (Aided), Erode, Tamil Nadu, India
}

\begin{abstract}
Cooperative action is being increasingly recognized as an ideal mechanism for securing the involvement of the people and for utilizing their self-help in the whole process of home building. Cooperatives allow members to pool resources to achieve greater benefits than they could as individuals. Cooperation in its literal sense means working together. However, in a technical sense, the term means working together for some economic pursuit, but based on certain basic principles and values. These essentially include idea of self help, mutual aid and defence of the poor against exploitation. This paper indeed concentrates on the borrowers preferences in selecting Cooperative Housing Societies as their agency and in turn the problems faced by the societies during distribution of loans.
\end{abstract}

Keywords: Cooperatives, self-help, housing societies, TNCHF, NCHF, housing loan.

\section{Introduction}

Housing is regarded as a basic human need along with food and clothing. Housing condition is an important indicator of the level of living of the people. It has been rightly observed in the National Sample Survey Report on Housing Conditions that housing conditions and related facilities determine the immediate environment of man. Housing condition is, therefore, recognized as an important indicator of the level of living. Adequate housing contributes directly to the individual health and productivity which are essential for national economic growth. Investment in housing has a multiplier effect on the economy through the concurrent development of allied industries.

\section{Statement of the Problem}

It was the motto and policy of the Government to provide a house for each family in Tamil Nadu. The Co-operative Housing Societies play an important role in achieving the above object. In Tamil Nadu State, there were 834 Urban Co-operative Housing Societies and 196 Taluk Rural Co-operative Housing Societies and along with a state level Apex Body namely Tamil Nadu Co-operative Housing Federation Limited functioning to cater the Housing needs of the members in urban and rural areas. In Erode district in 2015-16, there were 24 housing Co-operatives with a membership of Rs.4.3 lakhs and the working capital of Rs.27.23crores. As Housing Co-operatives have made appreciable progress in India, the study was designed to study the performance of Primary Co-operative Housing Societies in Erode District wherein eight Co-operative Housing Societies are functioning at the grass root level. In this juncture, it is imperative to examine the number of members in Co-operative Housing societies, mobilization and utilisation of resources, lending activities, problems faced by Co-operative Housing Societies and the satisfaction of the beneficiaries. 
Scope for the Study

Now a days shelter is one of the common need for any individual. Therefore, there is a significant scope to examine the need for housing loan, utilization level, financial performance of Co-operative Housing Societies, extent of overdue, problems faced by the Co-operative Housing Societies and its beneficiaries. To assess the performance level, eight sample societies are taken and compared. The study is made to analyse the extent of utilization level of members of sample Co-operative Housing Societies at Erode district. The study is confined only to the individuals who are the members of the Erode Cooperative Housing Society. The study is individual oriented and so the concept of utilization has been considered from the point of view of the members of sample Societies in Erode District and not from the point of view of the society.

\section{Objectives of the Study}

- To study the profile of Co-operative Housing Societies in Erode District.

- To analyze the financial performance of Co-operative Housing Societies in Erode District.

- To examine the extent of over dues in Co-operative Housing Societies in Erode District.

- To analyze members perception about the services offered by Co-operative Housing Societies in Erode District.

- To examine the problems of sample Co-operative Housing Societies and its beneficiaries and to offer suggestions.

\section{Hypothesis of the Study}

1. There is no significant relation between the type of house and demographic profile of the respondents.

2. There is no significant association between demographic variables and motivational factors.

3. There is no significant association between the level of satisfaction and the services provided by the Co-operative Housing Societies.

\section{Research Methodology}

The present study is an empirical one. Field survey method and personal interview technique have been adopted for the collection of the required data from the selected Co-operative Housing Societies and its members. The secondary data have been gathered from the institutions and primary data have been collected from the selected respondents by using schedules constructed for the purpose.

\section{Sampling Procedure}

Random sampling technique has been adopted for the study. Erode Revenue District has been selected purposively because of its unique characteristics. Erode district has been one of the industrially, Co-operatively and educationally developed district of Tamil Nadu state. The other considerations like proximity, financial and time factors have also contributed to select the particular district for an in-depth study. In Erode Revenue District, 8 Co-operative Housing Societies have been selected out of 24 by using simple random sampling method. The sample societies are listed below:

- The Erode Co-operative Housing Society Ltd.

- Perundurai Taluk Co-operative Housing Society Ltd.,

- Gobichettipalayam Co-operative Housing Society Ltd.,

- Tamil Nadu Transport Employees Co-operative Building Society.

- Erode Co-operative Building Society.

- Southern Railway Employees Co-operative House Building Society Ltd.,

- Perundurai Teachers and Staff of Education Department., Co-operative Housing Society Ltd.,

- Bhavani Cooperative Building Society Ltd., The main focus of the study was on the financial performance of Cooperatives Housing Societies in the study area. However, it is felt that any study on the performance of the housing Societies would not be completed without studying the satisfaction of its members. Therefore, the members' perception about the services offered by the sample societies has been included as another dimension which would help to vouch the result of the study. Totally 376 members have been selected for study.

\section{Tools Used}

\section{Chi-Square Analysis}

The chi-square analysis has been used to test the significance of the influence of demographic characters over the opinions of the borrowers. The 
chi-square statistic is

$$
\chi^{2}=\sum \frac{(O-E)^{2}}{E}
$$

Here O: Observed frequency E: Expected frequency.

\section{Average Score Analysis}

After converting the qualitative information into a quantitative one using a five point scale, the average scores were obtained on various issues to determine the mean scores regarding satisfaction regarding services. Parametric test of two sample t-Test and One way analysis of variance for more than two groups are applied to for judging the significance of the difference between means scores after testing the normality by Q-Q plot.

\section{Garrett Ranking}

Garrett ranking has been used to find out the most influential factor in motivating the borrowers to approach Cooperative Housing Societies for loan. As per this method, respondents have been asked to assign the rank for all factors and the outcomes of such ranking have been converted into score value with the help of the following formula:

Percent position $=100(\mathrm{Rij}-0.5) / \mathrm{Nj}$
Where,

Rij = Rank given for the ith variable by $j$ th respondents

$\mathrm{Nj}=$ Number of variable ranked by jth respondents

With the help of Garrett's Table, the percent position estimated is converted into scores.

\section{Profile of the Study Area}

In Erode District, there are 24 Housing Cooperatives effectively extending their services to the members. Among these cooperatives, Erode Cooperative Housing Society Limited was the age old society. It was registered on 24.03.1924. Next to this, Bhavani Cooperative Building Society and Gobi Cooperative Building Society were 65 years old cooperative institutions. Gobichettipalayam Cooperative Housing Society Limited was registered before 61 years. There were 7 societies come across with more than 50 years of registration. It was also observed that these societies have crossed above 40 years of age and the rest of the societies were below 40 years old. Olagadam Cooperative Housing Society was of recent origin than compared to other housing societies. This society has been rendering effective services to its members for the past 17 years in Olagadam.

\section{Membership Position}

Table 1 Membership Position (Nos.)

\begin{tabular}{|l|c|c|c|c|c|c|c|c|c|}
\hline \multicolumn{1}{|c|}{ Year } & ECHS & PTCHS & TTECBS & ECBS & GCHS & SRECHBS & PTSEDCHS & BCBS & TOTAL \\
\hline $2004-05$ & 5985 & 2485 & 6685 & 8710 & 9663 & 8003 & 13370 & 1412 & 56976 \\
\hline $2005-06$ & 5905 & 2516 & 6703 & 8714 & 9570 & 8741 & 13406 & 1316 & 57620 \\
\hline $2006-07$ & 5890 & 2653 & 6702 & 8751 & 9633 & 8359 & 13403 & 1280 & 57423 \\
\hline $2007-08$ & 5850 & 2613 & 6697 & 8756 & 9584 & 8327 & 13393 & 1125 & 57102 \\
\hline $2008-09$ & 5752 & 2613 & 4575 & 8756 & 9484 & 8356 & 9150 & 1009 & 52710 \\
\hline $2009-10$ & 5657 & 2617 & 4577 & 8724 & 9367 & 8337 & 9154 & 1898 & 53344 \\
\hline $2010-11$ & 5557 & 2616 & 4576 & 8728 & 9334 & 8308 & 9151 & 1706 & 52990 \\
\hline $2011-12$ & 5506 & 2616 & 4575 & 8728 & 9325 & 8289 & 9149 & 1643 & 52756 \\
\hline $2012-13$ & 5482 & 2600 & 4655 & 8728 & 9303 & 8277 & 9310 & 1619 & 52910 \\
\hline $2013-14$ & 5439 & 2515 & 4681 & 8728 & 9247 & 8250 & 9362 & 1586 & 52718 \\
\hline Mean & 5702.30 & 2584.40 & 5442.60 & 8732.30 & 9451.00 & 8324.70 & 10884.80 & 1459.40 & 54654.90 \\
\hline SD & 200.02 & 56.78 & 1080.01 & 16.49 & 153.17 & 179.05 & 2159.94 & 278.50 & 2273.15 \\
\hline CV & 3.51 & 2.20 & 19.84 & 0.19 & 1.62 & 2.15 & 19.84 & 19.08 & 4.16 \\
\hline
\end{tabular}

Source: Annual Reports of sample Co-operative Housing Societies

It is evident from the Table 1, that the total during the study period except PTCHS and ECBS number of members has decreased in all the societies

in which the change is either stable or consistent. 
The total number of members' for a period of ten years in all the societies has decreased from 56976 in 2004-05 to 52718 in 2013-14. The Co-efficient of Variation is 4.16.

Table No 2 Growth Rates of Membership (\%)

\begin{tabular}{|l|c|c|c|c|c|c|c|c|c|}
\hline $\begin{array}{c}\text { Growth } \\
\text { Rates }\end{array}$ & ECHS & PTCHS & TITECBS & ECBS & GCHS & SRECHBS & PTSEDCHS & BCBS & TOTAL \\
\hline AAGR & -1.06 & 0.16 & -3.24 & 0.02 & -0.49 & 0.39 & -3.24 & 4.32 & -0.83 \\
\hline LGR & -1.14 & 0.16 & -5.50 & 0.00 & -0.51 & -0.11 & -5.50 & 0.02 & -1.18 \\
\hline CGR & -1.14 & 0.17 & -5.2 & 0.00 & -0.51 & -0.1 & -5.2 & 3.47 & -1.16 \\
\hline
\end{tabular}

Source: Computed by the researcher

The average annual growth rate is maximum in BCBS with 4.32 percent while it is least in PTSEDCHS and TITECBS each with -3.24 percent. Linear growth rate is either negligible or negative in all the societies. Compound growth rate for all the

The average annual growth rate, linear growth rate and compound growth rate for all the sample Co-operative Housing Societies is given in Table 2.
Eleven basic mathematical models were used to fit these data. The objective is to find how best these the best model that fits the data. The following eleven mathematical models are used for this purpose. data fit into the models and choose the model which is societies is -1.16 percent.

1. Linear model

2. Quadratic model

3. Cubic model

4. Logarithmic model

5. Inverse model

6. Compound growth model

7. Power curve model

8. S curve model

9. Growth curve model

10. Exponential model

11. Logistic model
In all these equations $\mathrm{Y}$ represents as dependent variable, $\mathrm{t}$ - time and $\mathrm{b}_{0}$ as constant, $\mathrm{b}_{1}, \mathrm{~b}_{2}$ and $\mathrm{b}_{3}$ are growth coefficients. The best fitting model is identified by the highest $\mathrm{R}^{2}$ value, since $\mathrm{R}^{2}$ describes them the goodness of fit of the model. Once the best fit model is identified then the forecast for the next

$$
\begin{aligned}
& : Y=b 0+b 1 t \\
& : Y=b 0+b 1 t+b 2 t 2 \\
& : Y=b 0+b 1 t+b 2 t 2+b 3 t 3 \\
& : Y=b 0+b 1 \log t \\
& : Y=b 0+b 1 / t \\
& : Y=b 0 * b 1 t \\
& : Y=b 0 . t b 1 \\
& : Y=e(b 0+b 1 / t) \\
& : Y=e(b 0+b 1 t) \\
& : Y=b 0 . e b 1 t \\
& : Y=1 /[(1 / u)+(b 0 . b 1 t)] \text { where } u=\text { upper bound }
\end{aligned}
$$

few years were estimated using the model.

It is seen from the analysis that the cubic model has the highest $\mathrm{R}^{2}$ value and hence considered as the best fitting model compared with all other models. The model equations for the parameter for the Cooperative Housing Societies are;

$$
\begin{array}{ll}
\mathrm{Y}_{\text {ECHS }} & =5955.80+30.3726 \mathrm{t}-21.078 \mathrm{t} 2+1.2923 \mathrm{t}^{3} \\
\mathrm{Y}_{\text {PTCHS }} & =2403.90+90.9582 \mathrm{t}-10.195 \mathrm{t} 2+0.2405 \mathrm{t}^{3} \\
\mathrm{Y}_{\text {TITECBS }} & =6444.27+568.851 \mathrm{t}-236.52 \mathrm{t} 2+16.4483 \mathrm{t}^{3} \\
\mathrm{Y}_{\text {ECBS }} & =8659.47+52.9864 \mathrm{t}-9.6719 \mathrm{t} 2+0.5084 \mathrm{t}^{3} \\
\mathrm{Y}_{\text {GCHS }} & =9622.50+39.2951 \mathrm{t}-19.531 \mathrm{t} 2+1.2044 \mathrm{t}^{3} \\
\mathrm{Y}_{\text {SRECHBS }} & =7889.87+362.672 \mathrm{t}-71.250 \mathrm{t} 2+3.9116 \mathrm{t}^{3} \\
\mathrm{Y}_{\text {PTSEDCHS }} & =12888.8+1137.37 \mathrm{t}-473.01 \mathrm{t} 2+32.8967 \mathrm{t}^{3} \\
\mathrm{Y}_{\text {BCBS }} & =1894.73-551.05 \mathrm{t}+125.897 \mathrm{t} 2-7.4433 \mathrm{t}^{3} \\
\mathrm{Y}_{\text {TOTAL }} & =157.833+18.5876 \mathrm{t}-3.6451 \mathrm{t} 2+0.1612 \mathrm{t}^{3}
\end{array}
$$

Using the coefficient values of these models the forecast has been made for next few years i.e., for 2014, 2015 and 2016. 
Table 3 Forecasted Values of Membership

\begin{tabular}{|c|c|c|c|c|c|c|c|c|c|}
\hline Year & ECHS & PTCHS & TITECBS & ECBS & GCHS & SRECHBS & PTSEDCHS & BCBS & TOTAL \\
\hline 2014 & 5460 & 2491 & 5976 & 8749 & 9294 & 8464 & 11951 & 1160 & 55162 \\
\hline 2015 & 5518 & 2443 & 7635 & 8781 & 9363 & 8741 & 15270 & 549 & 58276 \\
\hline 2016 & 5628 & 2392 & 10005 & 8831 & 9479 & 9157 & 20010 & -345 & 62790 \\
\hline
\end{tabular}

Observing the estimates of these models it respectively, for BCBS is expected to be 1160, 549 can be predicted that the membership position for ECHS is expected to be 5460,5518 and 5628 for the years 2014-16 respectively, for PTCHS it is expected to be 2491, 2443 and 2392 for the years 2014-16 respectively, for TITECBS it is 5976, 7635 and 10005 for the years 2014-16 respectively, for ECBS it is 8749,8781 and 8831 for the years 2014-16 respectively, for GCHS it is 9294, 9363 and 9479 for the years 2014-16 respectively. The predicted membership position for SRECHBS is expected to be 5464, 8741 and 9157 for the years 2014-16respectively, for PTSEDCHS it is expected to be 11951, 15270 and 20010 for the years 2014-16 and -345 for the years 2014-16 respectively and the total membership position is expected to be 55162 , 58276 and 62790 for the years 2014-16 respectively

For the purpose of analyzing the equality of means for different parameter 'ANOVA' test is used. The following hypothesis is framed and tested by using ' $\mathrm{F}$ ' test to test the validity of the hypothesis.

Hypothesis H01: There is no significant difference in the mean membership position among the Cooperative Housing Societies.

Table 4 shows the mean and standard deviation of membership position of Co-operative Housing Societies.

Table 4 Inferential Statistics Membership Position

\begin{tabular}{|c|c|c|c|c|c|c|}
\hline Company & Mean & SD & SE & $\mathbf{F}$ & p & Decision \\
\hline ECHS & $5,702.30 \mathrm{c}$ & 200.02 & 63.25 & \multirow{8}{*}{149.694} & \multirow{8}{*}{$<0.001 * *$} & \multirow{8}{*}{ Reject H0 } \\
\hline PTCHS & $2,584.40 \mathrm{~b}$ & 56.78 & 17.96 & & & \\
\hline TTECBS & $5,442.60 \mathrm{c}$ & $1,080.01$ & 341.53 & & & \\
\hline ECBS & $8,732.30 \mathrm{~d}, \mathrm{e}$ & 16.49 & 5.22 & & & \\
\hline GCHS & $9,451.00 \mathrm{e}$ & 153.17 & 48.44 & & & \\
\hline SRECHBS & $8,324.70 \mathrm{~d}$ & 179.05 & 56.62 & & & \\
\hline PTSEDCHS & $10,884.80 \mathrm{f}$ & $2,159.94$ & 683.03 & & & \\
\hline BCBS & $1,459.40 \mathrm{a}$ & 278.50 & 88.07 & & & \\
\hline TOTAL & $6,572.69$ & $3,262.89$ & 364.80 & & & \\
\hline
\end{tabular}

** Significant at 1 percent

From the above table, it is observed that as the $\mathrm{p}$ value is less than 0.01 , null hypothesis is rejected at 1percent level of significance. i.e. membership position differs significantly between Co-operative Housing Societies. Having determined the differences that exist among the means, post hoc range tests can determine which means differ. Tucky's tests identified the homogeneous subsets of means that are significantly different from each other and the results are also given in the table $1.1 \mathrm{c}$ by showing the homogeneity subsets within which the groups fall in. The homogeneity subsets are shown by the letters a, $\mathrm{b}$ and $\mathrm{c}$ in the affix of the mean values.

\section{Problems Faced by the Co-Operative Housing Societies}

Co-operative Housing Societies face a number of problems before giving loans to its members.

1. The private sector banks get compromised if any one of the documents is not available. The sale deed, base document of the land, encumbrance certificate (for 15 years), house tax, electricity bill, water tax, patta, chitta, adangal, re-survey extract, topo sketch (field map), VAO certificate, age proof, income proof, Id proof, approval plan and engineers cost of estimation are the documents verified by the employees of the society.

2. The effectiveness of the societies is judged by 
the profit or loss accrued to them. The society must recover the entire outstanding amount and calculate the profit for the year. If there is profit, after holding up with the annual general meeting, the society can distribute the dividend to the share holders at 14 percent rate of interest. The percentage of dividend depends upon the decision of the quorum.

3. Accepting deposits and issue of jewel loan are also one of the functions of the Co-operative Housing Societies. The fixed deposits may be accepted for one year or two years. The interest rate for the deposits is 8 percent for one year and 8.5 percent for two years and an addition of 0.5 percent for senior citizens. The mortgage loan for jewel is issued at 12 percent. The difference of 4 percent is the margin amount to the society. However, the societies are not in a position to balance their income and expenditure and hence the society incurs losses.

4. The smooth functioning of the society depends on the cordial relation between the employer and the employee and also among the members too. In certain societies, there is no cordial relationship between the employees and the members.

5. Working capital is important for day-to-day activities. The deposits, accumulated interest on deposits, collection of dues and over dues, documentary charges, collection of penalty and interest from jewel loan form a part of the working capital of the Co-operative Housing Society. If there is failure in any of these items then the functioning of the society stammers.

6. The society disburses the loan to its borrowers from its collection. If the amount is not sufficient it can raise funds from $\mathrm{TNCHF}, \mathrm{NCHF}$ and other financial Institutions. Generally, they do not approach other institutions for funds. They try to run their society with their own funds.

7. The cost of construction is higher and the Co-operative Housing Societies are not able to meet the expectancy of the borrowers as per their limit.

8. Apart from the regular activities, a keen watch on the over dues is a must. They must give reminders for the non - payment of dues.
9. Political and Government interference is high in case of sanction and disbursement of loan.

\section{Research Findings}

- $\quad 52.93$ percent belongs to nuclear family. As the number of members in a nuclear family is less, the borrowing capacity is more.

- $\quad 54.26$ percent of the respondents have more than 4 members in their family while 32.71 percent of the members have 3-4 members. 13.03 percent have only two members.

- 82.4 percent have informed that there is no delay in sanctioning the loan. Only 66 respondents (17.55 percent) have stated that there is inordinate delay in sanctioning the loan.

- Overall level of satisfaction for all the selected Co-operative Housing Societies ranged between 63 percent to 100 percent. It is interesting to note that the satisfaction level is maximum in PTCHS which ranges between 70 percent -100 percent.

\section{Suggestions}

- The loan holders are married and this shows that the bachelors don't come forward to avail the housing loans from the Co-operative Housing Societies.

- The necessity of housing is a must for nuclear family and the same is has been resulted in the analysis.

- All the individuals should have the intention to own a house of their own as per their family status. The loan discharged through the Co-operative Housing Societies is not up to their usage. The maximum loan terms from Rs.5 lakhs to Rs.10 lakhs only. To build a house with 800 sq.ft. cost at least Rs. 15 lakhs. Hence, the societies can extend their loan discharge upto Rs.50 lakhs.

- The employees are the backbone of the societies. Their workload should be minimized and vacancies should be properly filled.

- It is suggested that the problem of housing should be fully solved by proper surroundings, good environment, and spacious accommodation with ventilation and clean drainage. 


\section{Conclusion}

During the study period, it was analyzed that the proper management of funds, creating awareness of the members, smooth relationship of the employer and employee is very essential. The societies have to reduce its loan procedures and receive as much as funds from TNCHF and NCHF. The functioning of the sample Co-operative Housing Societies also shows a declining trend. This is due to the financial deficit in the hands of the borrowers and also improper management of the financial institutions with regards to issue of loans, period of loans, terms and conditions, recovery, collection of over dues etc.

\section{References}

"National Urban Housing and Habitat policy Report (NUHHP)." Ministry of Housing and Urban Poverty Alleviation, Government of India, 2007.

Khurana M.L. "Climate Change and Cities - A Global Challenge" Tamilnadu Journal of co-operation, 2009, pp 5-10.

Sundaram P.S.A, "Mobilization of Funds and Lending for House Construction in Maharashtra", Housing Finance in India, Vol. 5, no. 1, 2000, pp. 100 .

\section{Author Details}

B.Jeeva Rekha, Assistant Professor in Commerce, Sri Vasavi College (Aided), Erode, Tamil Nadu, India, Email.ID: jeevarekhan@gmail.com. 